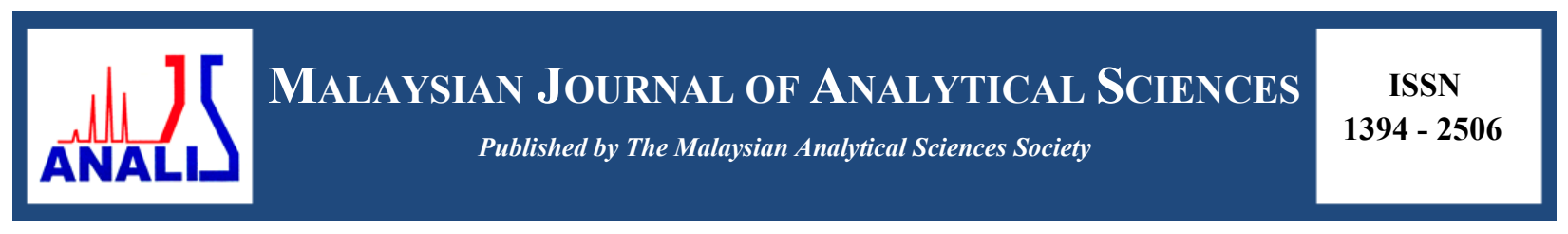

\title{
SYNTHESIS AND ANTIBACTERIAL STUDY OF ORGANOTIN(IV) COMPLEXES CONTAINING HYDRAZINOPYRIDINE LIGAND
}

\author{
(Sintesis dan Kajian Antibakteria Kompleks Organostanum(IV) yang Mengandungi Ligan \\ Hidrazinopiridin)
}

\author{
Dayang Norafizan A. Chee*, Monica Lulo Rodis, Norziah Saat, Zainab Ngaini, Ainaa Nadiah Abdul Halim \\ Department of Chemistry, Faculty of Resource Science and Technology, \\ Universiti Malaysia Sarawak, 94300 Kota Samarahan, Sarawak, Malaysia \\ *Corresponding author: dnorafizan@unimas.my
}

Received: 21 August 2016; Accepted: 27 July 2017

\begin{abstract}
Nowadays, the studies on organotin(IV) complexes with hydrazone ligand become more interesting due to their potential in various applications including medicinal area. In our recent studies, four new organotin(IV) complexes $\mathrm{MeSnCl}_{2}\left(\mathrm{C}_{12} \mathrm{H}_{12} \mathrm{~N}_{4}\right)(\mathbf{2})$, BuSnCl $2\left(\mathrm{C}_{12} \mathrm{H}_{12} \mathrm{~N}_{4}\right)(3), \mathrm{PhSnCl}_{2}\left(\mathrm{C}_{12} \mathrm{H}_{12} \mathrm{~N}_{4}\right)(4)$ and $\mathrm{Ph}_{2} \mathrm{SnCl}\left(\mathrm{C}_{12} \mathrm{H}_{12} \mathrm{~N}_{4}\right)$ (5) were synthesized by the direct reaction of methyl-2pyridylketone-2-hydrazinopyridine ligand (1) and organotin(IV) chloride(s) in absolute methanol. These complexes have been characterized by UV-Visible, FT-IR, ${ }^{1} \mathrm{H}$ and ${ }^{13} \mathrm{C}$ NMR spectroscopies. All of the synthesized compounds were screened for antibacterial activity against Escherichia coli and Staphylococcus aureus. However, the complexes showed weak activity against the bacteria compared to the free ligand.
\end{abstract}

Keywords: hydrazone ligand, spectral studies, coordination, biological potential

Abstrak

Pada masa ini, kajian tentang kompleks organostanum(IV) dengan ligan hidrazon semakin menarik kerana sangat potensinya dalam banyak aplikasi termasuk bidang perubatan. Dalam kajian ini, empat organostanum(IV) kompleks iaitu $\mathrm{MeSnCl}_{2}\left(\mathrm{C}_{12} \mathrm{H}_{12} \mathrm{~N}_{4}\right)$ (2), BuSnCl $2\left(\mathrm{C}_{12} \mathrm{H}_{12} \mathrm{~N}_{4}\right)$ (3), $\mathrm{PhSnCl}_{2}\left(\mathrm{C}_{12} \mathrm{H}_{12} \mathrm{~N}_{4}\right)$ (4) dan $\mathrm{Ph}_{2} \mathrm{SnCl}_{(2}\left(\mathrm{C}_{12} \mathrm{H}_{12} \mathrm{~N}_{4}\right)$ (5) telah disintesis melalui tindak balas terus metil-2-piridilketon-2-hidrazinopiridin ligan dan organostanum(IV) klorida di dalam metanol. Kesemua kompleks telah dicirikan oleh kajian spektrum UV-nampak, FTIR, ${ }^{1} \mathrm{H}$ dan ${ }^{13} \mathrm{C}$ RMN. Semua sebatian yang disintesis telah diuji untuk aktiviti antibakteria terhadap Escherichia coli dan Staphylococcus aureus. Walaubagaimanapun, kompleks menunjukkan aktiviti yang agak lemah menentang bakteria berbanding ligan bebas.

Kata kunci: ligan hidrazon, kajian spektra, koordinasi, potensi biologi

\section{Introduction}

Schiff base metal complexes containing hydrazone group have been studied extensively due to the interesting ligand systems containing different donor sites in heterocyclic rings. Hydrazones are the organic molecule that usually bonded to the metal atom through nitrogen and oxygen but also there was through sulphur atom. These hydrazone chelate derivatives also act as good potential oral drugs to cure the genetic disorders for example thalassemia [1]. Besides, hydrazones have many pharmacological properties including anti-tubercular activities and iron scavenging $[2,3]$. The biochemical activity of organotin compounds commonly depend on the structure of the molecule and the coordination number of the tin atoms [4]. Organotin(IV) complexes are known to stimulate therapeutic effects on 
various tumor cells [5]. Besides, Sharma and Kaushik [6] found that they are suitable as wood preservatives and active either towards Gram-positive or Gram-negative bacteria.

Thus, there are many of previous researchers reported on the potential of hydrazone metal complexes in biological activities. Bendre et al. [7] have been produced copper(II) complexes of 1,3-bis(2'-pyridyl)-1,2-diaza-2-butene and all of the synthesized compounds showed inhibition activities against mushroom tyrosinase. A few years later, organotin(IV) complexes with vitamin- $\mathrm{K}_{3}$-2-hydrazinopyridine have been successfully synthesized and evaluated for toxicity and anti-termitic potential by Affan et al. [8]. The result indicated that ligand and organotin(IV) moderately active against Artenia salina and Coptotermes sp. Again, organotin(IV) complexes with ortho-vanillin2-hydrazinopyridine exhibited better toxicity against $A$. salina and moderate to high activity against four types of bacteria which were Bacillus cereus, Staphylococcus aureus, Escherichia coli and Enterobacter aerogenes [9]. Evidently, the transition metal and organotin(IV) complexes with 2-hydrazinopyridine derivatives showed many potentials especially in biological activities studies.

Therefore, it is our interest to synthesize, characterize and evaluate the antibacterial activities of organotin(IV) complexes with methyl-2-pyridylketone-2-hydrazinopyridine. This is because this ligand contains $\mathrm{N}, \mathrm{N}$-donor atoms which are also still limited, plus the Sn-N coordination bond formed with complexes was believed to contribute to the antibacterial activities of the complexes.

\section{Materials and Methods}

Preparation of methyl-2-pyridylketone-2-hydrazinopyridine ligand (1)

A solution of methyl-2-pyridylketone $(0.242 \mathrm{~g}, 0.002 \mathrm{~mol})$ in ethanol $(10 \mathrm{~mL})$ was added dropwise to a refluxing ethanolic solution of 2-hydrazinopyridine $(0.218 \mathrm{~g}, 0.002 \mathrm{~mol})$. Three drops of concentrated sulphuric acid were added to the reaction mixture, which was later refluxed for 3 hours. Next, the reaction mixture was allowed to cool to room temperature for one hour. The pink precipitate formed were filtered off and the filtrate was evaporated until milky yellow colour precipitate form. The milky yellow precipitate obtained was recrystallized by slow evaporation of hot absolute ethanol solution at room temperature.

\section{Synthesis of [ $\left.\mathrm{MeSnCl}_{2}\left(\mathrm{C}_{12} \mathrm{H}_{12} \mathrm{~N}_{4}\right)\right](2)$}

The ligand $\left(\mathrm{C}_{12} \mathrm{H}_{12} \mathrm{~N}_{4}\right)(\mathbf{1})(0.212 \mathrm{~g}, 0.001 \mathrm{~mol})$ was dissolved in hot absolute methanol $(10 \mathrm{~mL})$ in a Schlenk round bottom flask. A methanolic solution of methyltin(IV) chloride $(0.240 \mathrm{~g}, 0.001 \mathrm{~mol})$ was added dropwise into the resulting mixture causing the solution to change from orange to red in colour. The solution was refluxed further for another 5 hours and allowed to cool to room temperature. The precipitate formed was filtered and finally dried in vacuum over silica gel overnight. The methyltin(IV) complex was obtained as shiny red precipitate by recrystallization from methanol.

Synthesis of [ $\left.\mathrm{BuSnCl}_{2}\left(\mathrm{C}_{12} \mathrm{H}_{12} \mathrm{~N}_{4}\right)\right]$ (3)

Complex 3 was synthesized using the same procedure as 2 with organotin(IV) chloride $(0.282 \mathrm{~g}, 0.001 \mathrm{~mol})$.

Synthesis of $\left[\mathrm{PhSnCl}_{2}\left(\mathrm{C}_{12} \mathrm{H}_{12} \mathrm{~N}_{4}\right)\right](4)$

Complex 4 was synthesized using the same procedure as 2 with organotin(IV) chloride (0.302 g, $0.001 \mathrm{~mol})$.

Synthesis of $\left[\mathrm{Ph}_{2} \mathrm{SnCl}\left(\mathrm{C}_{12} \mathrm{H}_{12} \mathrm{~N}_{4}\right)\right](5)$

Complex $\mathbf{5}$ was synthesized using the same procedure as $\mathbf{2}$ with organotin(IV) chloride $(0.343 \mathrm{~g}, 0.001 \mathrm{~mol})$.

\section{Antibacterial activity}

The antibacterial activity of ligand (1) and its complexes (2-5) were studied against Escherichia coli O157:H7 and Staphylococcus aureus using turbidimetric kinetic method [10]. The inoculums could grow on media containing nutrient broth at $37{ }^{\circ} \mathrm{C}$ with permanent shaking at $250 \mathrm{rpm}$ for 18 hours. $7 \mathrm{~mL}$ of culture medium with increasing concentration of the compounds dissolved in DMSO were inoculated with $0.14 \mathrm{~mL}$ of inoculums and the mixture was shaken again at $250 \mathrm{rpm}$ at $37{ }^{\circ} \mathrm{C}$. The solvent was used as negative control and the clinical antibiotic, amoxicillin was used as positive control. Aliquots of each replicate were taken at every 1 hour interval for 6 hours and the transmittance (T) was registered in a Metertech Plus SP-830 UV-Visible spectrophotometer. The 
antibacterial activity was determined by graph as $\mathrm{ln} \mathrm{Nt}$ which related to the number $\mathrm{cfu} / \mathrm{mL}$ (colony forming units $/ \mathrm{mL}$ ) for the bacteria versus time.

\begin{abstract}
Results and Discussion
Characterization study: Methyl-2-pyridylketone-2-hydrazinopyridine ligand (1)

Yield: $0.321 \mathrm{~g}$, 70\%. M.p: $82-83{ }^{\circ} \mathrm{C}$. UV-Visible (DMSO) $\lambda_{\max }(\mathrm{nm}): 331$. IR $\left(v_{\max } \mathrm{cm}^{-1}\right)(\mathrm{KBr}): 3343(\mathrm{NH}), 1605$ $(\mathrm{C}=\mathrm{N}), 994(\mathrm{~N}-\mathrm{N}), 776$ (pyridine in plane). ${ }^{1} \mathrm{H}$ NMR $\left(\mathrm{DMSO}-d_{6}, 500 \mathrm{MHz}\right) \delta: 9.98(\mathrm{~s}, 1 \mathrm{H}, \mathrm{NH}), 8.55(\mathrm{~d}, 1 \mathrm{H}, \mathrm{py}-$ $\left.\mathrm{H}_{6}\right), 7.68-8.16\left(\mathrm{~m}, 3 \mathrm{H}, \mathrm{py}-\mathrm{H}_{3}-\mathrm{H}_{5}\right), 6.84-7.32\left(\mathrm{~m}, 3 \mathrm{H}\right.$, pyridine ring), $2.39\left(\mathrm{~s}, 3 \mathrm{H}, \mathrm{CH}_{3}\right) \mathrm{ppm} .{ }^{13} \mathrm{C}$ NMR (DMSO- $d_{6}$, $500 \mathrm{MHz}) \delta$ : $157.21(1 \mathrm{C}, \boldsymbol{C}=\mathrm{N}), 107.34-155.80(10 \mathrm{C}$, pyridine ring $), 11.33\left(1 \mathrm{C}, \mathrm{H}_{3} \boldsymbol{C}-\mathrm{C}=\mathrm{N}\right) \mathrm{ppm}$.
\end{abstract}

\title{
$\left[\mathrm{MeSnCl}_{2}\left(\mathrm{C}_{12} \mathrm{H}_{12} \mathbf{N}_{4}\right)\right](2)$
}

Yield: $0.391 \mathrm{~g}, 87 \%$. M.p: $285-287^{\circ} \mathrm{C}$. UV-Visible (DMSO) $\lambda_{\max }(\mathrm{nm}): 331$, 499. IR $\left(v_{\max } \mathrm{cm}^{-1}\right)(\mathrm{KBr}): 3069(\mathrm{NH})$, $1599(\mathrm{C}=\mathrm{N}-\mathrm{N}=\mathrm{C}), 1001(\mathrm{~N}-\mathrm{N}), 781$ (pyridine in plane), $566(\mathrm{Sn}-\mathrm{C}), 414(\mathrm{Sn}-\mathrm{N}) .{ }^{1} \mathrm{H}$ NMR (DMSO- $\left.d_{6}, 500 \mathrm{MHz}\right)$ $\delta: 10.18(\mathrm{~s}, 1 \mathrm{H}, \mathrm{NH}), 8.55\left(\mathrm{~d}, 1 \mathrm{H}, \mathrm{py}-\mathrm{H}_{6}\right), 8.06-8.36\left(\mathrm{~m}, 3 \mathrm{H}, \mathrm{py}-\mathrm{H}_{3}-\mathrm{H}_{5}\right), 2.58\left(\mathrm{~s}, 3 \mathrm{H}, \mathrm{CH}_{3}\right), 1.57\left(\mathrm{~s}, 3 \mathrm{H}, \mathrm{Sn}-\mathrm{CH}_{3}\right)$ ppm. ${ }^{13} \mathrm{C}$ NMR (DMSO- $\left.d_{6}, 500 \mathrm{MHz}\right) \delta: 157.11(1 \mathrm{C}, \boldsymbol{C}=\mathrm{N}), 113.58-144.59$ (10C, pyridine ring), $12.14\left(1 \mathrm{C}, \mathrm{H}_{3} \boldsymbol{C}-\right.$ $\mathrm{C}=\mathrm{N}) 12.70\left(1 \mathrm{C}, \mathrm{Sn}-\mathrm{CH}_{3}\right) \mathrm{ppm}$.

\section{$\left[\mathrm{BuSnCl}_{2}\left(\mathrm{C}_{12} \mathrm{H}_{12} \mathrm{~N}_{4}\right)\right](3)$}

Yield: 0.320 g, $65 \%$. M.p: $253-254^{\circ} \mathrm{C}$. UV-Visible (DMSO) $\lambda_{\max }(\mathrm{nm}): 331,500$. IR $\left(v_{\max } \mathrm{cm}^{-1}\right)(\mathrm{KBr}): 3049(\mathrm{NH})$, $1597(\mathrm{C}=\mathrm{N}-\mathrm{N}=\mathrm{C}), 997(\mathrm{~N}-\mathrm{N}), 771$ (pyridine in plane), $565(\mathrm{Sn}-\mathrm{C}), 417(\mathrm{Sn}-\mathrm{N}) .{ }^{1} \mathrm{H}$ NMR (DMSO- $\left.d_{6}, 500 \mathrm{MHz}\right) \delta$ : $9.96(\mathrm{~s}, 1 \mathrm{H}, \mathrm{NH}), 8.77\left(\mathrm{~d}, 1 \mathrm{H}, \mathrm{py}-\mathrm{H}_{6}\right), 7.96-8.33\left(\mathrm{~m}, 3 \mathrm{H}\right.$, py- $\left.\mathrm{H}_{3}-\mathrm{H}_{5}\right), 6.74-7.75(\mathrm{~m}, 4 \mathrm{H}$, pyridine ring) $2.58(\mathrm{~s}, 3 \mathrm{H}$, $\mathrm{CH}_{3}$ ), 0.95-2.25 (m, 9H, Sn- $\left.\mathrm{CH}_{2} \mathrm{CH}_{2} \mathrm{CH}_{2} \mathrm{CH}_{3}\right) \mathrm{ppm} .{ }^{13} \mathrm{C}$ NMR (DMSO- $\left.d_{6}, 500 \mathrm{MHz}\right) \delta: 157.24(1 \mathrm{C}, \boldsymbol{C}=\mathrm{N}), 113.51-$ 144.82 (10C, pyridine ring), $12.17\left(1 \mathrm{C}, \mathrm{H}_{3} \mathrm{C}-\mathrm{C}=\mathrm{N}\right.$ ) ppm 30.09, 28.56, 25.20, 13.74 (4C, $\mathrm{Sn}-\mathrm{CH}_{2} \mathrm{CH}_{2} \mathrm{CH}_{2} \mathrm{CH}_{3}$ ).

\section{$\left[\mathrm{PhSnCl}_{2}\left(\mathrm{C}_{12} \mathrm{H}_{12} \mathbf{N}_{4}\right)\right](4)$}

Yield: 0.352 g, $85 \%$. M.p: $268-269^{\circ} \mathrm{C}$. UV-Visible (DMSO) $\lambda_{\max }(\mathrm{nm}): 332$, 406. IR $\left(v_{\max } \mathrm{cm}^{-1}\right)(\mathrm{KBr}): 3070(\mathrm{NH})$, $1598(\mathrm{C}=\mathrm{N}-\mathrm{N}=\mathrm{C}), 1000(\mathrm{~N}-\mathrm{N}), 778$ (pyridine in plane), $566(\mathrm{Sn}-\mathrm{C}), 445(\mathrm{Sn}-\mathrm{N}) .{ }^{1} \mathrm{H}$ NMR (DMSO- $\left.d_{6}, 500 \mathrm{MHz}\right)$ $\delta$ : $9.96(\mathrm{~s}, 1 \mathrm{H}, \mathrm{NH}), 8.55\left(\mathrm{~d}, 1 \mathrm{H}, \mathrm{py}-\mathrm{H}_{6}\right), 7.65-7.69\left(\mathrm{~m}, 5 \mathrm{H}, \mathrm{Sn}_{-} \mathrm{C}_{6} \mathrm{H}_{5}\right), 6.66-8.35$ (m, overlapping of pyridine-H and phenyl ring protons of phenyl ring attached to the center tin(IV) atom), $2.65\left(\mathrm{~s}, 3 \mathrm{H}, \mathrm{CH}_{3}\right) \mathrm{ppm} .{ }^{13} \mathrm{C}$ NMR (DMSO$\left.d_{6}, 500 \mathrm{MHz}\right) \delta$ : $157.08(1 \mathrm{C}, \boldsymbol{C}=\mathrm{N}), 113.74-144.37$ (pyridine $\left.\operatorname{ring} / \mathrm{Sn}-\boldsymbol{C}_{6} \mathrm{H}_{5}, 15 \mathrm{C}\right), 12.12\left(1 \mathrm{C}, \mathrm{H}_{3} \boldsymbol{C}-\mathrm{C}=\mathrm{N}\right) \mathrm{ppm}$.

\section{$\left[\mathrm{Ph}_{2} \mathrm{SnCl}\left(\mathrm{C}_{12} \mathrm{H}_{12} \mathrm{~N}_{4}\right)\right](\mathbf{5})$}

Yield: $0.256 \mathrm{~g}, 46 \%$. M.p: $269-270{ }^{\circ} \mathrm{C}$. UV-Visible (DMSO) $\lambda_{\max }(\mathrm{nm}): 331,496 . \mathrm{IR}\left(v_{\max } \mathrm{cm}^{-1}\right)(\mathrm{KBr}): 3068(\mathrm{NH})$, $1598(\mathrm{C}=\mathrm{N}-\mathrm{N}=\mathrm{C}), 999(\mathrm{~N}-\mathrm{N}), 778$ (pyridine in plane), $566(\mathrm{Sn}-\mathrm{C}), 446(\mathrm{Sn}-\mathrm{N}) .{ }^{1} \mathrm{H}$ NMR (DMSO- $\left.d_{6}, 500 \mathrm{MHz}\right) \delta$ : $9.95(\mathrm{~s}, 1 \mathrm{H}, \mathrm{NH}), 8.55\left(\mathrm{~d}, 1 \mathrm{H}, \mathrm{py}-\mathrm{H}_{6}\right), 7.28-7.93\left(\mathrm{~m}, 10 \mathrm{H}, \mathrm{Sn}-\left(\mathrm{C}_{6} \mathrm{H}_{5}\right)_{2}\right), 6.66-8.35(\mathrm{~m}$, overlapping of pyridine-H and phenyl ring protons of phenyl ring attached to the center tin(IV) atom), $2.65\left(\mathrm{~s}, 3 \mathrm{H}, \mathrm{CH}_{3}\right) \mathrm{ppm} .{ }^{13} \mathrm{C}$ NMR (DMSO$\left.d_{6}, 500 \mathrm{MHz}\right) \delta$ : $157.33(1 \mathrm{C}, \boldsymbol{C}=\mathrm{N}), 113.76-148.40\left(22 \mathrm{C}\right.$, pyridine ring/Sn- $\left(\boldsymbol{C}_{6} \mathrm{H}_{5}\right)_{2}, 12.13\left(1 \mathrm{C}, \mathrm{H}_{3} \boldsymbol{C}-\mathrm{C}=\mathrm{N}\right) \mathrm{ppm}$.

\section{Synthesis}

The methyl-2-pyridylketone-2-hydrazinopyridine (1) was initially synthesized by the acid-catalyzed condensation reaction of methyl-2-pyridylketone with 2-hydrazinopyridine in ethanolic solution in 1:1 mole ratio. Afterwards, four new organotin(IV) complexes (2-5) were synthesized by direct reaction of organotin(IV) chloride(s) with ligand (1) under nitrogen atmosphere. The organotin(IV) complexes were prepared as shown in Scheme 1. All the newly synthesized organotin(IV) complexes were coloured solids and soluble in DMSO, pyridine and DMF. 
<smiles>C/C(=N\Nc1ccccn1)c1ccccn1</smiles>

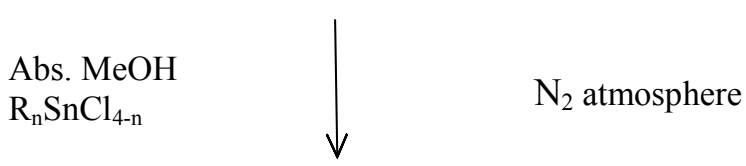<smiles></smiles>

$\begin{array}{ll}\mathrm{R}=\mathrm{Me} & \mathrm{X}=\mathrm{Cl} \\ \mathrm{R}=\mathrm{Bu} & \mathrm{X}=\mathrm{Cl} \\ \mathrm{R}=\mathrm{Ph} & \mathrm{X}=\mathrm{Cl} \\ \mathrm{R}=\mathrm{Ph} & \mathrm{X}=\mathrm{Ph}\end{array}$

Scheme 1. Synthesis route of organotin(IV) complexes (2-5)

\section{UV-visible spectra}

The absorption spectrum of ligand (1) was recorded in methanol with concentration of $1 \times 10^{-4} \mathrm{M}$ at room temperature. There is only one absorption band appeared at $\lambda_{\max }$ of 331 which are suggested to be causes by $n-\pi^{*}$ transition of imine group. The electronic absorption spectra of complex (2-5) were also recorded in DMSO at room temperature. The first peak at $331-332 \mathrm{~nm}$ region is attributed to $\mathrm{n}-\pi^{*}$ transition which has bathochromic shift suggested the free imine $(>\mathrm{C}=\mathrm{N})$ group of ligand (1) is coordinated to the tin(IV) atoms. Another new peak in the range 496-502 $\mathrm{nm}$ indicated the complexation occurred via ligand-to-metal transfer (LMCT) transition [11].

\section{Infrared spectra}

To clarify the mode of the ligand coordination to the tin centre, IR spectra in the range of $4000-400 \mathrm{~cm}^{-1}$ were recorded. The IR spectrum of ligand (1) in showed the peak appeared at $3343 \mathrm{~cm}^{-1}$ was assigned to NH strectching bond. Another important stretching bands are at 1605 and $994 \mathrm{~cm}^{-1}$ which are assigned to $v(\mathrm{C}=\mathrm{N}), v(\mathrm{~N}-\mathrm{N})$ and $v$ (pyridine in plane), respectively.

Upon complexation, the stretching vibration azomethine $(\mathrm{C}=\mathrm{N})$ is shifted to the lower frequency in all complexes (2-5) indicating that azomethine nitrogen is involved in coordination with $\operatorname{tin}(\mathrm{IV})$ ion [1]. The $v(\mathrm{~N}-\mathrm{N})$ stretching vibration value also shifted to the higher frequency which is $997-1001 \mathrm{~cm}^{-1}$ compared to the free ligand further supporting that the coordination of azomethine nitrogen to the $\mathrm{Sn}(\mathrm{IV})$ atom. A very strong band of v(pyridine in plane) also showed increases in its value after complexation compared to the free ligand which is $776 \mathrm{~cm}^{-1}$. The band of $v$ (pyridine in plane) went to the higher frequencies at $778-781 \mathrm{~cm}^{-1}$ in all complexes (2-5), indicating that the pyridyl ring nitrogen involved in coordination to the $\mathrm{Sn}(\mathrm{IV})$ atom. This is probably because of the occurrence of electron reduction upon complexation [8]. 
Besides, a new band has been identified at $414-446 \mathrm{~cm}^{-1}$ in all the organotin complexes (2-5) confirming that there were $\mathrm{Sn}-\mathrm{N}$ bond have been formed and showed that the coordination occurred at azomethine nitrogen and pyridine$\mathrm{N}$ atom. Furthermore, the new band of $v(\mathrm{Sn}-\mathrm{C})$ also indicating that alkyl or aryl group coordinated to the $\mathrm{Sn}(\mathrm{IV})$ atom [8].

\section{${ }^{1}$ H NMR spectra}

The ligand (1) showed resonance signals at 9.98, 8.55, 7.68-8.16, $6.84-7.32$ and 2.39 ppm due to the $\mathrm{NH}$, py- $\mathrm{H}_{6}$, py- $\mathrm{H}_{3}-\mathrm{H}_{5}$, pyridine ring and $\mathrm{H}_{3} \mathrm{C}-\mathrm{C}=\mathrm{N}$ respectively. The ${ }^{1} \mathrm{H}$ NMR spectra of complexes (2-5) were also successfully obtained. Upon complexation, the NH resonance signals for the complex (2) shifted to the downfield region (10.18 $\mathrm{ppm})$ while complexes (3-5) shifted to the upfield region $(9.95-9.96 \mathrm{ppm})$. This showed the occurrence of complexation $\mathrm{NH}-\mathrm{C}=\mathrm{N}$ nitrogen atom to the tin(IV) atom. The py- $\mathrm{H}_{6}$ signal shifted to downfield region at $8.55-$ $8.87 \mathrm{ppm}$ compared to the free ligand (1) in all complexes (3-5), suggesting the involvement of pyridyl ring nitrogen atom in the coordination to tin(IV). Other signals for pyridine ring protons were also shifted to the downfield region but the signals could not be identified properly because of the overlapping of pyridyl ring protons. The $\mathrm{H}_{3} \mathrm{C}-\mathrm{C}=\mathrm{N}$ resonance signal for complexes (3-5) shifted to the downfield region $(2.58-2.65 \mathrm{ppm})$ compared to the free ligand (1) also supported the complexation of $\mathrm{H}_{3} \mathrm{C}-\mathrm{C}=\mathrm{N}$ nitrogen atom to the tin(IV) atom. In complex (2), a sharp resonance signal appeared as singlet at $1.57 \mathrm{ppm}$ attributed to methyl group attached to tin(IV) atom. The resonance signals were appeared at $0.95-2.25 \mathrm{ppm}$ in spectra of complex (3) assigned to the butyl group attached to tin(IV) atom. Complexes (4) and (5) exhibited multiplet signals in the region of $7.28-7.93 \mathrm{ppm}$ due to the $\mathrm{Sn}-\mathrm{Ph}$ protons.

\section{${ }^{13}$ C NMR Spectra}

The ${ }^{13} \mathrm{C}$ NMR spectrum of free ligand (1) showed the resonance signals at 157.21, $107.34-155.80$ and 11.33 are due to the $\delta(\boldsymbol{C}=\mathrm{N}), \delta$ (pyridine ring) and $\left(\mathrm{H}_{3} \boldsymbol{C}-\mathrm{C}=\mathrm{N}\right)$, respectively. After complexation, the carbon signals of the $\boldsymbol{C}=\mathrm{N}$ group shifted to the $157.08-157.33 \mathrm{ppm}$ in the complexes (2-5) when comparing to the ligand (1), indicating participation of the $\boldsymbol{C}=\mathrm{N}$ group in coordination to the tin(IV) atom. Besides, the coordination of ligand (1) to the tin(IV) atom can be observed through the chemical shifts shown by $\mathrm{H}_{3} \boldsymbol{C}-\mathrm{C}=\mathrm{N}$ in the free ligand (1) was observed at $11.33 \mathrm{ppm}$ which were shifted to down field region at $12.12-12.17 \mathrm{ppm}$. These observations indicated that the azomethine-N is coordinated to the tin(IV) moiety [12]. The $\delta$ value of carbon atoms in pyridine ring slightly shifted to upfield in the complexes (2-5) as compared to the free ligand showed that the pyridine ring nitrogen coordinated to the $\mathrm{Sn}(\mathrm{IV})$ atom.

The methyl group attached to the tin(IV) core appeared at $12.70 \mathrm{ppm}$ in complex (2). The butyl group attached to the organotin(IV) moiety in complex (3) gave four resonance signals at 30.09, 28.56, 25.20 and $13.74 \mathrm{ppm}$. Apart from that, the phenyl group in complexes (4) and (5) probably overlapped with pyridine ring from ligand (1) and result to the appearance of the resonance signals at $113.74-148.40 \mathrm{ppm}$.

\section{Antibacterial activity}

The antibacterial activities of ligand (1) and its complexes (2-5) were assayed at the concentration 50, 80, $100 \mathrm{ppm}$ against bacteria $E$. coli $\mathrm{O} 157: \mathrm{H} 7$ and $S$. aureus at $37^{\circ} \mathrm{C}$. The antibacterial activities of ligand (1) and complexes (25) were compared with DMSO and amoxicillin as a control. All the synthesized compounds demonstrated a quite similar of bacteriostatic activities upon introduction at different concentrations. The equation of $\ln \mathrm{N}_{\mathrm{t}}=27.1-8.56 \mathrm{~T}$ was used to indicate the condition of the microbial specific growth and the amount of drug concentration used. The graph of control showed inactive for antibacterial activity, when tested against $E$. coli. The effect of ligand (1) and complexes (2-5) was also further shown by their minimum inhibitory concentrations (MIC). The MIC of these compounds were determined by extrapolating the concentration at the zero growth rate of $E$. coli $(\mu=0)$. Compound with the MIC value $>200 \mathrm{ppm}$ is not suitable to be used as antibacterial agent for clinical purpose [13]. The MIC of these compounds were determined by extrapolating the concentration at the zero-growth rate of bacteria $(\mu=0)$.

Table 1 shows the MIC values for all synthesized compounds. According to the table, MIC value for ligand (1) was lower than $200 \mathrm{ppm}$, while all complexes (2-5) were greater $200 \mathrm{ppm}$. Based on the results, almost all organotin complexes (2-5) showed weak activities against E. coli and S. aureus. Meanwhile, the antibacterial activity of the 
ligand (1) showed relatively better antibacterial activity than all of the complexes. Among all of the complexes, complex (5) showed the moderate activity against the bacteria strain. Hence, the coordination of tin(IV) atom to the ligand did not raise much of the antibacterial activities. The presence of phenyl group in the complexes (4) and (5) bonded with the tin atom can improve the antibacterial activity, however in this scenario it is turned out into moderate activity. This is due to the presence of steric hindrance which is preventing the active sites to contact receptor site of the bacteria [9].

Table 1. MIC of ligand (1) and complexes (2-5)

\begin{tabular}{lcc}
\hline \multirow{2}{*}{ Compound } & \multicolumn{2}{c}{ MIC (ppm) } \\
\cline { 2 - 3 } & E. coli & S. aureus \\
\hline $\mathrm{C}_{12} \mathrm{H}_{12} \mathrm{~N}_{4}(\mathbf{1})$ & 128 & 160 \\
{$\left[\mathrm{MeSnCl}_{2}\left(\mathrm{C}_{12} \mathrm{H}_{12} \mathrm{~N}_{4}\right)\right](\mathbf{2})$} & $>200$ & 339 \\
{$\left[\mathrm{BuSnCl}_{2}\left(\mathrm{C}_{12} \mathrm{H}_{12} \mathrm{~N}_{4}\right)\right](\mathbf{3})$} & $>200$ & 372 \\
{$\left[\mathrm{PhSnCl}_{2}\left(\mathrm{C}_{12} \mathrm{H}_{12} \mathrm{~N}_{4}\right)\right](\mathbf{4})$} & $>200$ & $>200$ \\
{$\left[\mathrm{Ph}_{2} \mathrm{SnCl}_{2}\left(\mathrm{C}_{12} \mathrm{H}_{12} \mathrm{~N}_{4}\right)\right](\mathbf{5})$} & 463 & 204 \\
$\mathrm{Amoxicillin}$ & $>200$ & 85 \\
\hline
\end{tabular}

In addition, the chloride ion(s) in the structure of the complexes (2-5) should be improved the antibacterial activity due to the ability of chloride(s) ion to kill the microbes by inhibiting the multiplication of the bacteria through blockage of the bacteria active sites [9]. However, the presence of the chloride(s) ion in this complexes series did not contribute much to the activity of the complexes. Generally, all the synthesized compounds also more effective against Gram positive bacteria. When comparing the MIC values of the compounds with the clinical antibiotic, amoxicillin, all of the compounds have better activities against $E$. coli but weak activities against $S$. aureus. Figure 1 and 2 shows the inhibition activities of compounds (1-2) towards E. coli shown as $\ln N_{\mathrm{t}}$ for E. coli growth $v s$. time and inhibition activities of compounds (1-2) towards $S$. aureus shown as $\ln N_{\mathrm{t}}$ for $S$. aureus growth vs. time, respectively.

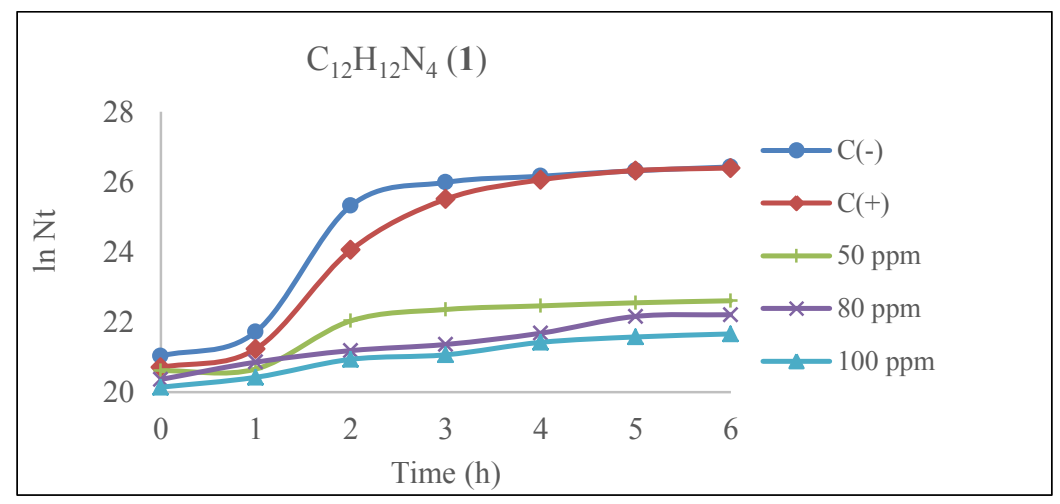




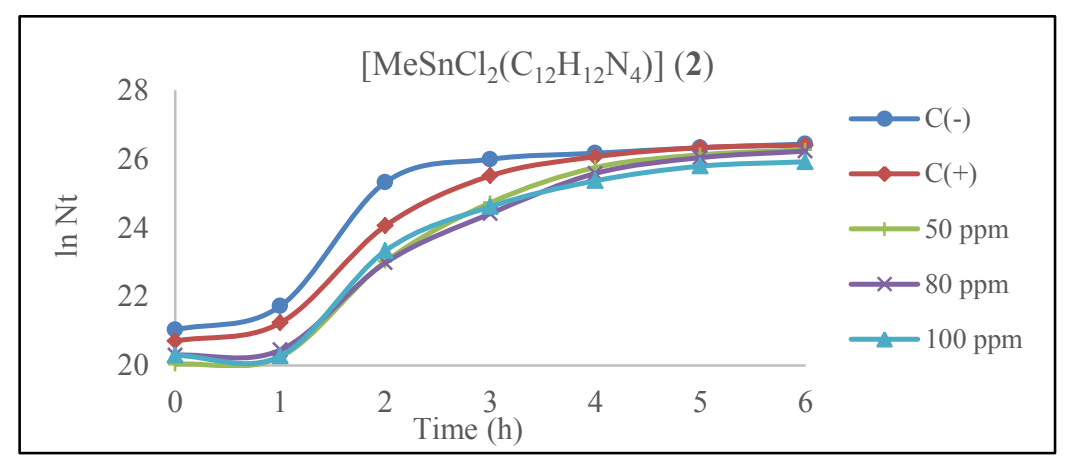

Figure 1. Inhibition activities of compounds (1-2) towards E. coli shown as $\ln N_{\mathrm{t}}$ for $E$. coli growth $v s$. time
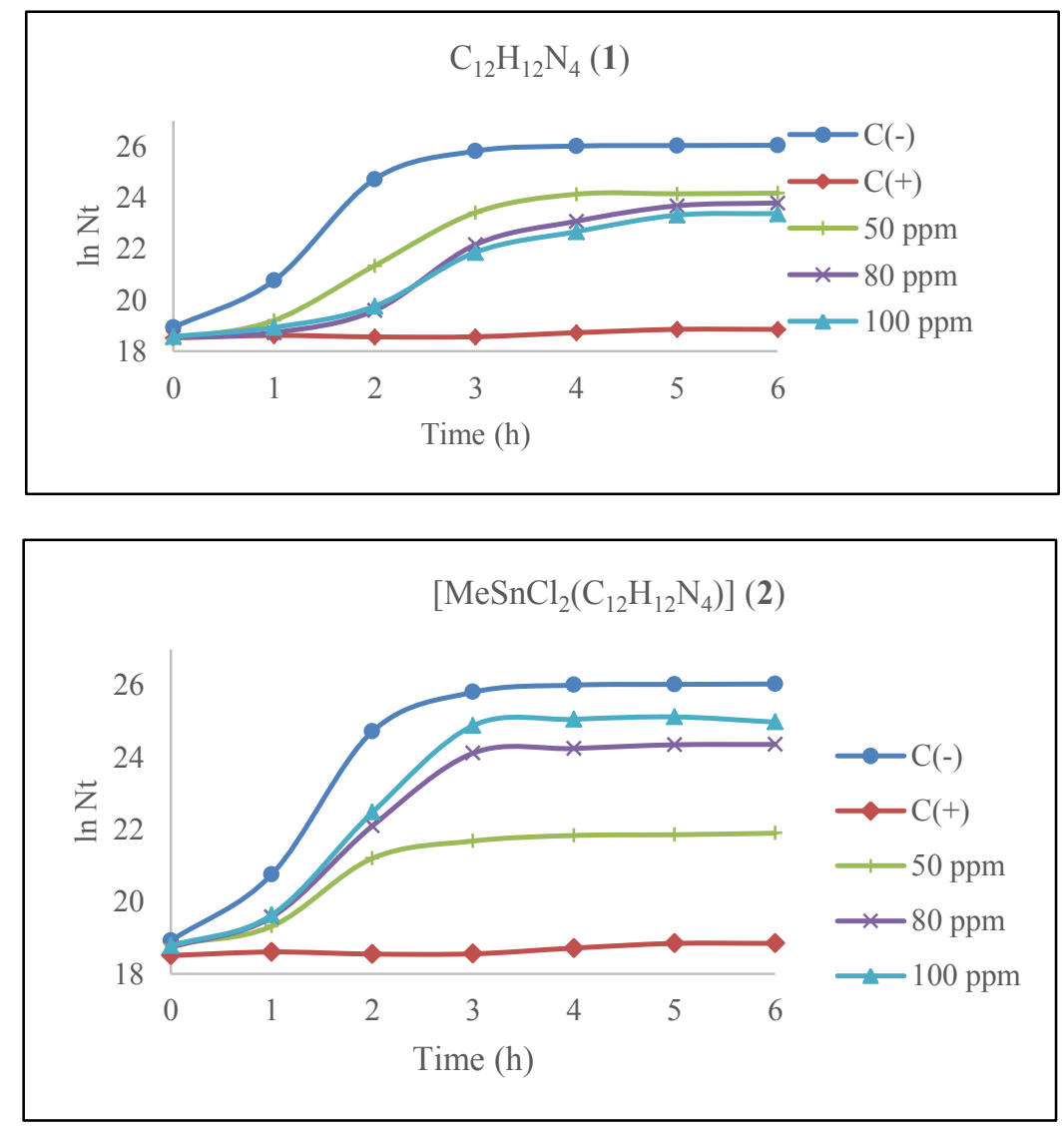

Figure 2. Inhibition activities of compounds (1-2) towards $S$. aureus shown as $\ln N_{\mathrm{t}}$ for $S$. aureus growth $v$ s. time

\section{Conclusion}

From the spectral analysis, it is suggested the bonding of ligand to the Sn(IV) atom was at the azomethine nitrogen $(\mathrm{C}=\mathrm{N})$ and pyridyl nitrogen atoms. The antibacterial activity evaluation showed that the complexation does not raise the antibacterial activities of the complexes in this study since ligand showed better activity than all of the 


\section{Dayang Norafizan et al: SYNTHESIS AND ANTIBACTERIAL STUDY OF ORGANOTIN(IV) COMPLEXES CONTAINING HYDRAZINOPYRIDINE LIGAND}

complexes. Therefore, it is recommended to investigate more on structure-activity relationship in order to improve the activity of the complexes and screened the antibacterial activities against more than one species of bacteria.

\section{Acknowledgment}

The authors would like to thank for the financial support provided from research grant of Universiti Malaysia Sarawak (UNIMAS) (RAGS/ST01(1)/1040/2013(07)) and all the person involved in this study.

\section{References}

1. Datta, A., Huang, J. and Machura, B. (2012). Octahedral complexes of cobalt(III) and nickel(II) incorporating with unsymmetrical NNO-donor hydrazone ligand: Synthesis and structural aspects. Journal of Chemical Crystallography, 42(7): $691-696$.

2. Suvapura, L. N, Young, K. S., Sung, O. B and Ammireddy. (2012). Review on analytical and biological applications of hydrazones and their metal complexes. E-Journal of Chemistry, 9(3): 1288 - 1304.

3. Seleem, H. S. and Mousa, M. A. (2011). Ligand substitution reactions of a phenolic quinolyl hydrazone; oxidovanadium (IV) complexes. Chemistry Central Journal, 5(47): 1 - 7.

4. Graisa, A., Farina, F Y., Yousif, E. and Kassem, M. (2008). Synthesis and characterization of some diorganotin(IV) complexes of N-toyl-m-nitrobenzohydroxamic acid. Journal of Engineering and Applied Sciences, 3(6): $47-50$.

5. Szorcsik, A., Nagy, L., Gajda-Schrantz, K., Pellerito, L., Nagy, E. Nagy and Edelmann, F. T. E. (2002). Structural studies on organotin(IV) complexes formed with ligands containing $\{\mathrm{S}, \mathrm{N}, \mathrm{O}$,$\} donor atoms. Journal$ of Radioanalytical and Nuclear Chemistry, 252(3): 523 - 530.

6. Sharma, R. and Kaushik, N. K. (2004). Thermal studies on some organotin(IV) complexes with piperidine and 2-aminopyrdithiocarbamates. Journal of Thermal Analysis and Colorimetry, 78(2004): 953 - 964.

7. Bendre, R. Murugkar, A., Padhye, S., Kulkami, P and Karve, M. (1998). Synthesis and characterization of coordinatively unsaturated copper(II) complexes of 1,3-bis(2'-pyridyl)-1,2-diaza-2-butene and their antityrosinase activity. Metal Based Drugs 5(2): $59-66$.

8. Affan, M. A., Chee, D. N. A, Ahmad, F. B., J. I., Yamin, M. Y and Hitam, R. B. (2010). Synthesis, characterization and biological activities of organotin(IV) complexes with vitamin $\mathrm{K}_{3}$-2-hydrazinopyridine: $\mathrm{X}$ ray crystal structure of vitamin $\mathrm{K}_{3}$-2-hydrazinopyridine [VHzP]. Research Journal of Pharmaceutical, Biological and Chemical Sciences 1(4): $158-172$.

9. Sam, N., Affan. M. A., Salam, M. A., Ahmad, F. B. and Asaruddin, M. R. (2012). Synthesis, spectral characterization and biological activities of organotin(IV) complexes with ortho-vanillin-2-hydrazinopyridine (VHP). Open Journal of Inorganic Chemistry, 2: $22-27$.

10. Li, R. C., Nix, D. E. and Schentag, J. J. (1993). New turbidimetric assay for quantitation of visible bacterial densities. Antimicrobial Agents Chemotherapy, 37(2): 371 - 374.

11. Affan, M. A., Foo, I. P. P., Ahmad, F. B., Sim, E. U. H. and Hapipah, M. A. (2009). Synthesis, structural characterization and toxicity studies of novel organotin(IV) complexes derived from benzoylacetone isonicotinylhydrazone $\left(\mathrm{H}_{2} \mathrm{BAS}\right)$ : X-ray crystal structure of $\left[\mathrm{Me}_{2} \mathrm{Sn}(\mathrm{BAS})\right]$. Malaysian Journal of Analytical Sciences, 13(1): $73-85$.

12. Salam, M. A., Affan, M. A., Arafat, M. A., Saha, R. and Nasrin, R. (2013). Synthesis, characterization and antibacterial activities of organotin(IV) complexes with 2-acetylpyridine- $N(4)$-cyclohexylthiosemicarbazone (HAPCT). Heteroatom Chemistry, 24(1): 43 - 52.

13. Pappano, N. B., Centorbi, O. P. and Ferretti, F. H. (1994). Determination of the responsible molecular zone for the chalcones bacteriostatic activity. Revista de Microbiologia, 24: 168 - 174.

14. Arslan, H., Duran, N., Borekci, G., Ozer, C. K. and Akbay, C. (2009). Antimicrobial activity of some thiourea derivatives and their nickel \& copper complexes. Molecules, 10(14): 519 - 527. 